Hersh, M. and Leporini, B. (2018) Serious games, education and inclusion for disabled people editorial. British Journal of Educational Technology, 49(4), pp. 587-595.

There may be differences between this version and the published version. You are advised to consult the publisher's version if you wish to cite from it.

This is the peer reviewed version of the following article:

Hersh, M. and Leporini, B. (2018) Serious games, education and inclusion for disabled people editorial. British Journal of Educational Technology, 49(4), pp. 587-595. (doi: 10.1111/bjet.12650)

This article may be used for non-commercial purposes in accordance with Wiley Terms and Conditions for Self-Archiving.

http://eprints.gla.ac.uk/163525/

Deposited on: 07 January 2018

Enlighten - Research publications by members of the University of Glasgow http://eprints.gla.ac.uk/ 


\title{
Serious Games, Education and Inclusion for Disabled People Editorial
}

\author{
Marion Hersh ${ }^{1}$ and Barbara Leporini ${ }^{2}$ \\ ${ }^{1}$ Biomedical Engineering, University of Glasgow, Scotland marion.hersh@glasgow.ac.uk \\ ${ }^{2}$ ISTI - CNR, Pisa, Italy \\ barbara.leporini@isti.cnr.it
}

\section{Introduction: The Need for Serious Games for Disabled People}

Digital games of all types, including serious games, are becoming increasingly popular. For instance, the serious games market was estimated to be worth between $\$ 2$ and 10 billion in 2012 (SGA, 2012) and growing at a rate of $16.38 \%$ to $\$ 5.45$ billion by 2020 (Anon, 2015), with the different figures arising from different definitions of serious games (SGA, 2012). The popularity of serious games is further illustrated by the growing number of companies, conferences and publications devoted to them (Breuer and Bente, 2010). At the same time continuing developments in information and communications technologies (ICT) are leading to increases in the sophistication and potential of these games and the development and proliferation of games on mobile devices, while game development has facilitated technological advances in ICT. For instance, advances in computer graphics hardware have contributed to game development and the success of video games has contributed to an increase in the quality of real-time computer graphics, enabling an associated increase in the realism of computer games (Anderson et al., 2010). Mobile educational games are also becoming popular and their sales overtook those of non-mobile games a few years ago (SGA, 2012). There are indications that serious games could be very powerful learning tools (Girard et al., 2013). However, there is still a need for empirical studies of their effectiveness in supporting learning. In addition, students are spending more time playing video games than reading and ICT is an integral part of their lives (Deshpande and Huang, 2009). This gives a need for the development of learning approaches based on the media actually used by learners, which very definitely include games, while not excluding learners who prefer more traditional approaches.

There is also a very welcome increase in recognition of the needs of disabled learners and the importance of integrating disabled students into mainstream education, as well as the importance of doing this appropriately and the associated requirement for adequate resources to support this (Avramidis et al. 2002; Center et al, 1985). There is still much more limited awareness of the needs of disabled teachers, lecturers and other disabled staff members, and many still face considerable disadvantage (Ewens et al., 2011; Sang, 2017) and further work is required in this area. However, there are issues of the extent to which disabled students are being fully integrated or included into mainstream education and the availability of resources to do this. For instance, a self-assessment tool was developed by the Entelis Project for inclusive schools using assistive technology (Hoogerwerf et al., 2017).

However, game development has generally focused on the non-disabled population (Grammenos et al., 2009) rather than taking a design for all approach (Connell et al. 1997; CEN 2003) to make the game playable and enjoyable for as diverse a population as possible. Designing serious games for learning is a complex task, as they have to be successful both as enjoyable and exciting games and in supporting learning. The main approaches to designing educational games are (i) starting with educational content and adding game elements; (ii) starting with a game and adding educational content; and (iii) trying to include an effective balance between design for engagement and motivation and design for learning from the start (Moreno-Ger et al., 2008). Designing games suitable for disabled people may then be seen as an added layer of complexity rather than an essential element of good game design. 
Most existing games have strong visual elements (Annetta and Bronack, 2008), making them inappropriate without modification for many blind and partially sighted people. The importance of sound and visual special effects in many games will make them less attractive to sensorily impaired players unless there are alternative equally attractive effects. Many games require a fast response which presents a barrier to many disabled people. However, slowing them down could make the game less interesting and exciting. Many games also raise accessibility and usability issues for disabled players (Hersh and Leporini, 2012). Accessible systems have input and output environmental characteristics which enable particular (groups of) users to access and use all the facilities of the system. Usable systems enable particular (groups of) users in their particular context to carry out the intended function(s) or achieve specified goals effectively, efficiently and with satisfaction (Federici et al. 2005). For instance, a graphical hyperlink button to go to another page which lacks an alt text link is not accessible to screen reader users, as the screen reader can only read text, not graphics. A shopping site which asks the user to confirm they have entered the correct delivery address, but does not provide a button to click to do this is not usable by any users, as they are unable to complete their transaction of buying goods. A site where the button is there, but difficult to find is also not usable, as looking for it will waste time and cause users irritation. Many disabled people access the information and communication technologies that act as platforms for digital games through assistive technology, such as onscreen or adapted keyboards, Braille displays and screen readers. Thus, accessibility for these players includes compatibility of the game and access to its full functionality with the assistive device (Hersh and Leporini, 2012).

There have been some approaches to designing games for disabled people. For instance several studies have investigated the design of video games with additional or customised input and output modalities for people with particular impairments (Grammenos et al., 2009, Yuan et al., 2011). A number of design suggestions and frameworks have been proposed (Darin et al., 2017; Torrente Vigil et al, 2014), including one for mobile educational games (Shoukry et al., 2015). However, they are not necessarily fully inclusive, with, for instance, the framework in (Shoukry et al., 2015) not covering visually impaired students.

When game accessibility has been considered, this has generally been for a particular group of disabled people e.g. blind or deaf people rather than disabled people in general. For instance audio games have been developed specifically for blind people, including (Balan et al., 2014; Drossos et al., 2015; Girard et al., 2013) and two audio learning games on TeacherMate, an inexpensive mobile device designed for people in majority world (developing) countries (Song et al., 2011). A list of 'screen-reader friendly' online games can be found at (http://www.whitestick.co.uk/ongames.html) and of audiogames without visual output at http://audiogames.net/listgames.php. Both sites have links to the game home page, but do not indicate the educational potential of the games.

The games UA Chess, Access Invaders and Terrestrial Invaders have been designed to be accessible to several different groups of disabled people (Grammenos et al, 2009). While a considerable advance on accessibility for a particular group of disabled users, it is still far from the universal accessibility claimed or a holistic design for all approach. The required accessibility features are recorded and set using user profiles. To avoid accessibility barriers at the start, the dialogue box for setting up the profile has a number of accessibility features. However, the availability of serious and other games for disabled players is only a fraction of the wide choice able to non-disabled ones. This gives a need for design for all approaches which take into account accessibility issues and the needs of a much wider range of users. There is also evidence of the potential for the use of digital games in rehabilitation and physical therapy (Martins et al., 2014), but still limited application in the rehabilitation of disabled and older people (Leporini and Hersh, 2016). 
This brief overview shows the increasing importance and potential of serious games in all types of learning and the limited attention given to the needs of disabled people in designing them. This makes it imperative that serious games for learning are designed to take account of the needs of disabled students and staff and ensure their full inclusion. Doing so will contribute to improving the learning and educational opportunities of disabled people and supporting their full inclusion into society. Not doing so will widen the digital divide and further disadvantage disabled people in many areas of life.

\section{Paper Overview}

As shown in table 1, the 14 papers provide a good overview of the diverse field of serious games for the inclusive education of disabled people. There is a wide geographical spread, and games for different age group, learning topics or themes and different groups of disabled people. However, games for vocational education and non-disability related academic education, as well as games that can be used with disabled people with different impairments are lacking. A number of different features are used to make the design attractive and accessible.

\begin{tabular}{|c|c|c|c|c|c|}
\hline Abbreviated Title & $\begin{array}{l}\text { Type of } \\
\text { Paper }\end{array}$ & \begin{tabular}{|l} 
Target \\
Learners
\end{tabular} & $\begin{array}{l}\text { Aims/Learning } \\
\text { Topics }\end{array}$ & Special Features & $\begin{array}{l}\text { Authors' } \\
\text { Country }\end{array}$ \\
\hline $\begin{array}{l}\text { Games for } \\
\text { enhancing basic } \\
\text { reading and maths } \\
\text { skills for learning } \\
\text { disabled people }\end{array}$ & Review & $\begin{array}{l}\text { intellectually } \\
\text { disabled } \\
\text { children }\end{array}$ & $\begin{array}{l}\text { reading and } \\
\text { maths }\end{array}$ & $\begin{array}{l}\text { engagement \& } \\
\text { motivation } \\
\text { through } \\
\text { context fantasy } \\
\text { and } \\
\text { audiovisual }\end{array}$ & Finland \\
\hline $\begin{array}{l}\text { Accessible } \\
\text { electronic games for } \\
\text { blind children }\end{array}$ & $\begin{array}{l}\text { Design } \\
\text { framework }\end{array}$ & \begin{tabular}{|l|} 
blind \\
children
\end{tabular} & $\begin{array}{l}\text { produce } \\
\text { accessible } \\
\text { games }\end{array}$ & $\begin{array}{l}\text { sonification } \\
\text { Memor-i studio } \\
\text { platform }\end{array}$ & Greece \\
\hline $\begin{array}{l}\text { Inclusive sound and } \\
\text { music in a large- } \\
\text { scale responsive } \\
\text { environment }\end{array}$ & Game & $\begin{array}{l}\text { blind (and } \\
\text { other) } \\
\text { children }\end{array}$ & $\begin{array}{l}\text { music and } \\
\text { not veering }\end{array}$ & $\begin{array}{l}\text { musical } \\
\text { sequences \& } \\
\text { movement }\end{array}$ & Italy \\
\hline $\begin{array}{l}\text { Videogame: } \\
\text { cardiopulmonary } \\
\text { resuscitation for } \\
\text { blind people }\end{array}$ & Game & Blind adults & CPR & $\begin{array}{l}\text { mini games for } \\
\text { the main CPR } \\
\text { actions }\end{array}$ & Spain \\
\hline $\begin{array}{l}\text { Design for } \\
\text { somebody approach }\end{array}$ & $\begin{array}{l}\text { Design } \\
\text { framework } \\
+ \text { games }\end{array}$ & $\begin{array}{l}\text { disabled } \\
\text { people, } \\
\text { people with } \\
\text { particular } \\
\text { needs } \\
\end{array}$ & $\begin{array}{l}\text { physical, } \\
\text { cognitive \& } \\
\text { social skills }\end{array}$ & personalisation & Finland \\
\hline $\begin{array}{l}\text { Game learning } \\
\text { analytics: validating } \\
\text { learning game for } \\
\text { intellectually } \\
\text { disabled adults }\end{array}$ & Game & $\begin{array}{l}\text { intellectually } \\
\text { disabled } \\
\text { adults }\end{array}$ & $\begin{array}{l}\text { use public } \\
\text { transport to } \\
\text { travel in } \\
\text { Madrid }\end{array}$ & $\begin{array}{l}\text { learning } \\
\text { analytics to } \\
\text { validate game } \\
\text { design }\end{array}$ & Spain \\
\hline $\begin{array}{l}\text { Applying Learning } \\
\text { Analytics in Serious } \\
\text { Games for People } \\
\text { with Intellectual } \\
\text { Disabilities }\end{array}$ & $\begin{array}{l}\text { Design } \\
\text { framework }\end{array}$ & $\begin{array}{l}\text { intellectually } \\
\text { disabled } \\
\text { adults }\end{array}$ & $\begin{array}{l}\text { Design } \\
\text { accessible } \\
\text { games for } \\
\text { ID adults }\end{array}$ & $\begin{array}{l}\text { support focus } \\
\text { on accessibility }\end{array}$ & $\begin{array}{l}\text { New } \\
\text { Zealand }\end{array}$ \\
\hline Opportunities and & Design & intellectually & Various & Importance of & Scotland \\
\hline
\end{tabular}




\begin{tabular}{|c|c|c|c|c|c|}
\hline $\begin{array}{l}\text { challenges of } \\
\text { serious games for } \\
\text { intellectually } \\
\text { disabled people }\end{array}$ & framework & $\begin{array}{l}\text { disabled } \\
\text { adults }\end{array}$ & & $\begin{array}{l}\text { psychological } \\
\text { profile, socio- } \\
\text { emotional } \\
\text { aspects, } \\
\text { culture, } \\
\text { context }\end{array}$ & $\begin{array}{l}\text { and } \\
\text { England }\end{array}$ \\
\hline $\begin{array}{l}\text { Designing an } \\
\text { augmented tabletop } \\
\text { game for children } \\
\text { with cognitive } \\
\text { disabilities }\end{array}$ & Game & $\begin{array}{l}\text { cognitively } \\
\text { disabled } \\
\text { children }\end{array}$ & $\begin{array}{l}\text { independent } \\
\text { living }\end{array}$ & $\begin{array}{l}\text { Touchscreen \& } \\
\text { printed card } \\
\text { interface }\end{array}$ & Greece \\
\hline $\begin{array}{l}\text { Serious games: } \\
\text { flexibility in thinking } \\
\text { in } \\
\text { neuropsychological } \\
\text { rehabilitation }\end{array}$ & Game & $\begin{array}{l}\text { older } \\
\text { people } \\
\text { post-stroke }\end{array}$ & $\begin{array}{l}\text { Flexible } \\
\text { thinking, } \\
\text { every day } \\
\text { activities }\end{array}$ & $\begin{array}{l}\text { activities } \\
\text { based on } \\
\text { news, films, } \\
\text { videos, games }\end{array}$ & Italy \\
\hline $\begin{array}{l}\text { Virtual collaborative } \\
\text { gaming as social } \\
\text { skills training for } \\
\text { autistic children }\end{array}$ & Game & $\begin{array}{l}\text { autistic } \\
\text { children }\end{array}$ & social skills & $\begin{array}{l}\text { 3D virtual } \\
\text { playground }\end{array}$ & USA \\
\hline $\begin{array}{l}\text { Autistic youth in 3D } \\
\text { game-based } \\
\text { collaborative virtual } \\
\text { learning }\end{array}$ & Game & $\begin{array}{l}\text { autistic } \\
\text { young } \\
\text { people }\end{array}$ & social skills & $\begin{array}{l}\text { avatar- } \\
\text { mediated } \\
\text { game-based } \\
\text { collaboration }\end{array}$ & China \\
\hline $\begin{array}{l}\text { Speech training for } \\
\text { neurological patients } \\
\text { using a serious } \\
\text { game }\end{array}$ & Game & $\begin{array}{l}\text { people with } \\
\text { dysarthia }\end{array}$ & $\begin{array}{l}\text { Speech } \\
\text { training }\end{array}$ & $\begin{array}{l}\text { various } \\
\text { accessibility } \\
\text { features }\end{array}$ & $\begin{array}{l}\text { Nether- } \\
\text { lands }\end{array}$ \\
\hline $\begin{array}{l}\text { Can cooperative } \\
\text { video games } \\
\text { encourage inclusion } \\
\text { of at-risk students? }\end{array}$ & Game & $\begin{array}{l}\text { at-risk of } \\
\text { social } \\
\text { exclusion }\end{array}$ & $\begin{array}{l}\text { Danish, } \\
\text { maths, } \\
\text { social } \\
\text { participation }\end{array}$ & $\begin{array}{l}\text { cooperative } \\
\text { action role- } \\
\text { playing game }\end{array}$ & Denmark \\
\hline
\end{tabular}

Table 1: Overview of the papers

Games for enhancing basic reading and maths skills: A systematic review of
educational game design in supporting learning by people with learning disabilities by Joni Lämsäa et al. presents a review of the recent literature on the use of serious games to support people with learning difficulties in particularly basic mathematics and reading. Games can encourage and motivate learning disabled children to practice difficult to learn skills. The flexibility of mini games and the greater interest of larger games can be combined through a series of linked mini games. Content-based adaptation and feedback systems were found to be the key beneficial gamification features. Context, fantasy and audio-visual aspects of the games should be designed to engage children in the gameplay. The research also identified the need to draw on both the learning disability and gaming design research to improve games for learning disabled people.

Accessible electronic games for blind children by George Giannakopolous et al. presents a framework using modern sonification strategies and the Memor-i-Studio platform for designing educational games for blind children and young people. This platform can be used to support game design by users without a technical background, including blind people with assistance. The approach was illustrated by the development of several audio games. In-game support and guidance, different sound sets, choice of voice for the game 'ally' and the option of including the player's voice were used to improve accessibility and 
attractiveness. Game evaluation by children and young people from a school and rehabilitation centre for blind people in Athens was very positive, encouraging further development and application of the approach.

Inclusive sound and music serious games in a large-scale responsive environment by Maria Mandanici et al. illustrates the use of a large scale responsive environment with embedded musical features to teach blind children music and to walk without veering. The musical features were used to stimulate interest and support learning and further research is planned to develop richer soundscapes and the involvement of more than one learner at a time. Three games were presented and tested with non-disabled and blind children. The quantitative and qualitative results show that the approach promotes task engagement and successful completion of activities. The authors also plan to develop the environment further to support participation of other groups of disabled people, including those with mobility impairments through the use of tablets or smartphones.

CPR for blind, a videogame to introduce cardiopulmonary resuscitation protocol to blind people by Antonio Rodriguez et al. is possibly the first video game introducing CPR training for blind people. A series of mini-games is used to introduce the main CPR steps proposed by the European Resuscitation Council using sound, vibration and tactile input and output. Tests with blind and sighted participants showed that playing the game led to an improvement in CPR knowledge and that blind participants in particular enjoyed the game and found it easy to play.

Designing serious games for special user groups - Design for Somebody approach by Sari Merilampi et al. presents a iterative user-oriented approach (Design for Somebody) to developing serious games (and other technologies) for disabled and other minority group users. The approach is illustrated by case studies of three games for encouraging physical, cognitive and social skill development. The paper describes the use of 3D printing and mobile and sensor technologies to support disabled and other users. The paper also shows the benefits of modular thinking and that the multidisciplinary approach increases understanding of user requirements and possible solutions. Resistance to change is reduced and commitment increased by involving all stakeholders.

\section{Using Game Learning Analytics for Validating the Design of a Learning Game for} Adults with Intellectual Disabilities by Ana Rus Cano et al. presents Downtown, A subway Adventure, a new game to complement existing training to enable intellectually disabled adults to travel independently in Madrid by public transport. A user centred approach was used in game development and end-users from the Madrid Down's Syndrome Foundation tested the game each time it was modified. Game analytics were used to collect and analyse data both off-line and in near-real time while users were playing the game. Overall their ability to travel improved and mistakes decreased and almost all students were able to complete at least one route without any mistakes.

\section{A Framework for Applying Learning Analytics in Serious Games for People with Intellectual Disabilities by Andy Nyugen et al. proposes a systematic framework for applying learning analytics as a design tool for the creation of inclusive games for people with intellectual disabilities. This is one of the few studies to date of the use of learning analytics in serious game design for disabled people. The framework comprises the three components of learner profiling, learner adaptation and learning evaluation. This framework is able to support educational technologists and researchers in taking account of the accessibility requirements of intellectually disabled people when designing serious games.}

The Opportunities and Challenges of Serious Games for People with an Intellectual Disability by Melody Terras et al. highlights the importance of user-centred design which situates game design for disabled people within the wider game design framework to 
maximise inclusion in game play and facilitate the use of state of the art technology and theory to design the most effective games for them. The paper further considers the need to take into account the external and internal contexts of the player, including the impacts of their psychological profile on game use and effectiveness. It concludes with the need for a multidisciplinary approach and a integrated conceptual framework for game design to take account of diversity in learning needs.

Designing an augmented tabletop game for children with cognitive disabilities: the "Home game" case by Maria Korozi et al. presents a new multi-modal interactive game for training children with cognitive impairments to live independently. The participatory design approach involved educators at a rehabilitation centre. The game uses a variety of exercises incorporating multimedia, virtual environments, tangible and playful interaction to facilitate learning the main rooms of a house, daily routines, and how to avoid inappropriate or hazardous behaviours. Accessibility and interest are promoted through the use of simple, but appealing game graphics and simple, direct language to enhance comprehension and two input modalities: touchscreen and printed cards.

\title{
CREC: The Role of Serious Games in Improving Flexibility in Thinking in
}

Neuropsychological Rehabilitation by Laura Colautti et al. presents a new training programme to support people returning home after a stroke. It includes two serious games to support transferring learnt strategies to the home environment. The overall aim is to encourage flexible thinking. The training is made accessible and attractive by including activities based on news, films, riddles and games and relating it to every day situations. Tests with six people who had experienced a stroke a year ago found an improvement in quality of life and several cognitive functions, including creative thinking. Participants considered they had become more effective problem solvers and that the serious games had helped them reflect critically on their lives.

\section{Virtual Collaborative Gaming as Social Skills Training for High-Functioning Autistic Children by Fengfeng Ke \& Jewoong Moon presents a 3D virtual playground constructed with Open Simulator and involving different types of gaming encourage social interaction by autistic children.. Options for autistic learners to participate in the design and modification of virtual gaming are used to increase their sense of agency and expression of identity, including when they need of a break from sensory overstimulation and external interactions. Interest is increased by framing the practice of social skills by core gameplay action. A mixed methods study with autistic children found that virtual reality game play does promote their social interaction and that the gameplay should be adopted to their reactions and abilities.}

\begin{abstract}
Autistic Youth in 3D Game-Based Collaborative Virtual Learning: Associating Avatar Interaction Patterns with Embodied Social Presence by Xianhui Wang examines avatarmediated verbal and non-verbal interactions by autistic young people in a 3D virtual playground construced in the collaborative learning environment iSocial. The underlying theory of the approach is based on the concept of embodied social presence. The study involves three cohorts of autistic young people aged 11-13 participating in 13 game activities in iSocial. Cluster analysis was carried out using video data of participant screen recordings. The results showed the need to reconceptualise collaborative 3D game based learning in virtual environments to centre upon experience and exploration. They also showed the importance of considering the unique characteristics of social interactions in 3D game based collaborative learning virtual environments.
\end{abstract}

Speech training for neurological patients using a serious game by Mario Ganzeboom et al. presents the two-player co-operative game Treasure Hunters. It is designed to help players with a motor speech impairment (dysarthia) due to, for instance Parkinson's disease and stroke, increase the loudness and reduce the pitch of their speech to improve 
intelligibility. Accessibility was increased by the use of large tap buttons, good colour contrast, a log that could be consulted to reduce the need for memorising and uncluttered game screens. An evaluation of the approach with elderly people with dysarthia due to Parkinson's disease or a stroke compared it to non-game computer-based speech training. Participants generally enjoyed the game, but the impacts on performance were mixed, indicating that personalised approaches may be required. In addition, there is a need for further testing with a large sample including women.

\section{Can cooperative video games foster social and motivational inclusion of at-risk}

students? by Thorkild Hanghøj et al. describes the use of game based learning activities in lower secondary classrooms with students defined to be 'at-risk' due to a lack of social participation and/or motivation to learn. It combined the commercial co-operative role playing game Torchlight II with analogue gamification features. The approach was used to create more inclusive classrooms through team collaboration in game-based mathematics and Danish learning activities. The study showed an increase in 'at-risk' students' feelings of well being,and a reduction in their feelings of external pressure to study, but more complex effects on performance. The results also indicate that the impact of game-based classrooms is due to reframing social participation and student engagement with the curriculum rather than their fun elements.

\section{Conclusions}

The articles show the wide interest in inclusive educational games, covering both the design of games and design approaches and frameworks for a wide range of disabled learners. However, game development has focused on games for disabled people with particular impairments, rather than the use of design for all approaches to develop games for disabled and non-disabled people with a wide range of different characteristics, including different impairments. While the games have a wide range of learning aims and topics, they are slanted more to rehabilitation and therapy and vocational and non-impairment related academic learning are less well represented. For instance, one of the two games teaching mathematics and reading targets learners with specific learning difficulties in these areas and the two games for autistic children and young people cover social rather than academic and vocational skills.

Some, though by no means all, of the games are grounded in particular pedagogical theories. The work generally shows some evidence of game effectiveness with regard to both enjoyment and meeting learning objectives. However, in most cases testing has involved only a small number of participants and short time periods, indicating the need for large scale trials. Authors have generally recognised the importance of the involvement of end-users in game development and in one case comment on the value of learner involvement in game design and modification in increasing their sense of agency and identity. However, in some cases end-users have only been involved in testing not design. Where testing has involved end-users, it has not always included disabled people. Where end-users have been involved in game development, this has often been restricted to teachers rather than disabled children or other disabled learners. This probably indicates a lack of researcher confidence in involving disabled people, including in testing devices and obtaining suggestions and feedback from them. There is consequently a need to develop strategies for effective communication, presentation of information and obtaining feedback from disabled people and to communicate these strategies to researchers. There may also be a need to develop more effective ways of motivating disabled people to participate in research and, where this can be done safely, to enable them to participate in familiar and/or nearby locations rather than laboratories to reduce travel and stress. A related issue is the potential mismatch between the perspectives of disabled learners and game designers, 
giving the possibility of games that do not meet learner needs. This can be resolved by much greater involvement of disabled learners in game design right from the start.

A variety of approaches, including input and output options, game features, game activities, in-game support and technology features, have been used to increase accessibility and/or interest and motivation of disabled learners/players. Input and output options include sound, vibration and tactile input and output; a choice of touchscreen and printed cards; good colour contrast and large buttons. Game activities include those based on new films and riddles, multimedia activities, activities related to everyday life and activities which players are likely to find relevant. Game features include embedded musical features, simple, but appealing game graphics, a game 'ally' with choice of voice, the option of including the player's voice and simple, but direct language. In-game support includes ingame support and guidance, a log which can be consulted to reduce memory demands and quiet areas of the game to withdraw to if overwhelmed. Technology features include 3D printing and mobile and sensor technologies and virtual environments. Other than games from different countries being developed in different languages, there were no obviously culturally specific features in the different games or features which made them obviously unsuited to different cultural contexts.

The papers presenting new games are complemented by those that present new frameworks and approaches to design, some of which are illustrated through applications in particular games. They include the use of game analytics in designing and validating games, the design for somebody approach which focuses on user characteristics and a platform for the development of audio memory games for blind people.

The papers in this special issue indicate the value of serious games for disabled learners. However, considerable further work is still required in a number of areas. This should include games available in several different languages, targeting a wider range of disabled learners and aimed at academic and vocational subjects. There is also a need for large scale testing of new and existing games. There is also a need for the development of further design philosophies and approaches for developing inclusive games, as well as games for specific groups of disabled people, and a need for the development of easy to apply techniques for making existing games fully accessible. The development of platforms to support and facilitate the design of accessible games with particular features, including by disabled people, is also essential. There is also a need for further work on the features required to provide accessibility, interest and motivation in serious games for disabled learners and the approaches for involving disabled people in game design.

\section{References}

Anderson, E. F., McLoughlin, L., Liarokapis, F., Peters, C., Petridis, P., \& De Freitas, S. (2010). Developing serious games for cultural heritage: a state-of-the-art review. Virtual reality, 14(4), 255-275.

Annetta, L. A., \& Bronack, S. (2008). Serious educational games. Theory into practice, 83. Anon (2015). Serious Game Market by Vertical (Education, Corporate, Healthcare, Retail, Media and Advertising), Application (Training, Sales, Human Resource, Marketing), Platform, End-User (Enterprise, Consumer), and Region - Forecast to 2020. http://www.marketsandmarkets.com/Market-Reports/serious-game-market67640395.html, accessed 27.6.2017.

Avramidis, E., \& Norwich, B. (2002). Teachers' attitudes towards integration/inclusion: A review of the literature. European journal of special needs education, 17(2), 129-147.

Balan, O., Moldoveanu, A., Moldoveanu, F., \& Dascalu, M. I. (2014). Audio games-a novel approach towards effective learning in the case of visually-impaired people. In 
Proceedings of seventh international conference of education, research and innovation, Seville.

Breuer, J. S., \& Bente, G. (2010). Why so serious? On the relation of serious games and learning. Eludamos. Journal for computer game culture, 4(1), 7-24.

CEN (2003). CEN workshop agreement CWA 14661. Guidelines to standardisers of ICT products and services in the CEN ICT domain, from ftp://cenftp1.cenorm.be/PUBLIC/CWAs/e-Europe/DFA/cwa14661-00-2003-Feb.pdf, accessed 12.8.2010.

Center, Y., Ward, J., Parmenter, T., \& Nash, R. (1985). Principals' attitudes towards the integration of disabled children into regular schools. Exceptional Child, 32(3), 149-61.

Connell, B.R. et al. (1997). The principles of universal design version 2.0, from http://www.design.ncsu.edu/cud/about_ud/udprinciplestext.htm, accessed 11.8.2010.

Darin, T. G., Andrade, R., Merabet, L. B., \& Sánchez, J. H. (2017). Investigating the Mode in Multimodal Video Games: Usability Issues for Learners who are Blind. In Proceedings of the $2017 \mathrm{CHI}$ Conference Extended Abstracts on Human Factors in Computing Systems (pp. 2487-2495). ACM.

Deshpande, A. A., \& Huang, S. H. (2011). Simulation games in engineering education: A state of the art review. Computer Applications in Engineering Education, 19(3), 399-410.

Drossos, K., Zormpas, N., Giannakopoulos, G., \& Floros, A. (2015). Accessible games for blind children, empowered by binaural sound. In Proceedings of the 8th ACM International Conference on Pervasive Technologies Related to Assistive Environments (p. 5).

Ewens, D., C. Nightingale, C. Law, S. Challenger and K. Byford (2011). Enabling equality: furthering disability equality for staff in higher education. https://www.ecu.ac.uk/wpcontent/uploads/external/enabling-equality-furthering-disability-equality-for-staff-inHE.pdf. Accessed 11.5.2018.

Federici, S. et al. (2005). Checking an Integrated Model of Web Accessibility and Usability Evaluation for Disabled People. Disability and Rehabilitation, vol. 27(13), 781-790.

Girard, C., Ecalle, J., \& Magnan, A. (2013). Serious games as new educational tools: how effective are they? A meta-analysis of recent studies. Journal of Computer Assisted Learning, 29(3), 207-219.

Grammenos, D., Savidis, A., \& Stephanidis, C. (2009). Designing universally accessible games. ACM Computers in Entertainment, vol. 7(1), 8:1-8:28.

Hersh, M.A. and Leporini, B. (2012). Accessibility and usability of educational games for disabled students, In C. Gonzalez, Student Usability in Educational Software and Games: Improving Experiences, pp. 1-40, IGI Global.

Hoogerwerf, E-J., Solander-Gross, A., Mavrou, K. Traina, I. and Hersh, M. (20017). A selfassessment framework for inclusive schools supporting tssistive technology users, AAATE, Toulouse, France.

Leporini, B. and Hersh, M.A. (2016). Games for the rehabilitation of disabled people. Rehab 2016, Lisbon, Portugal.

Martins, T., Araújo, M., Carvalho, V., Soares, F., \& Torrão, L. (2014). PhysioVinci-A first approach on a physical rehabilitation game. In International Conference on Serious Games Development and Applications (pp. 1-9). Springer, Cham.

Moreno-Ger, P., Burgos, D., Martínez-Ortiz, I., Sierra, J.L. and Fernández-Manjón, B. (2008). Educational game design for online education, Computers in Human Behaviour, vol. 24, pp. 2530-2540.

Sang, K. (2017). Disability and academic careers. Heriot Watt University Report.

SGA (2012). Serious games now $\$ 2$ to $\$ 10$ billion industry. http://www.hypergridbusiness.com/2012/08/serious-games-now-a-multi-billion-dollarindustry/, accessed 27.06.2017.

Shoukry, L., Sturm, C., \& Galal-Edeen, G. H. (2015). Pre-MEGa: A Proposed Framework for the Design and Evaluation of Preschoolers' Mobile Educational Games. In Innovations and Advances in Computing, Informatics, Systems Sciences, Networking and Engineering (pp. 385-390). Springer International Publishing. 
Song, D., Karimi, A., \& Kim, P. (2011, December). Toward designing mobile games for visually challenged children. In e-Education, Entertainment and e-Management (ICEEE), 2011 International Conference on (pp. 234-238). IEEE.

Torrente Vigil, F. J., Blanco Aguado, Á. D., Serrano Laguna, Á., Vallejo Pinto, J. A., Moreno Ger, P., \& Fernández Manjón, B. (2014). Towards a low cost adaptation of educational games for people with disabilities. Computer Science and Information Systems, 11(1), 369-391.

Yuan, B., Folmer, E., \& Harris, F. C. (2011). Game accessibility: a survey. Universal Access in the Information Society, 10(1), 81-100. 